\title{
Tingkat Kemandirian Mahasiswa Pendidikan Sains Pada Konsep Diagram Gaya
}

\author{
Tri Wahyuni Maduretno \\ STKIP PGRI Nganjuk \\ Email: maduretno@stkipnganjuk.ac.id
}

Received July 10, 2017; Revised August 1, 2017; Accepted September 29, 2017

\begin{abstract}
Abstrak
Tujuan penelitian adalah mengetahui tingkat kemandirian mahasiswa Pendidikan Sains pada mata kuliah Mekanika pada konsep Diagram Gaya. Penelitian ini termasuk deskriptif kualitatif dengan subjek penelitian mahasiswa Pendidikan Sains semester III Tahun Akademik 2016/2017 secara purposive sampling. Pengumpulan data menggunakan metode tes tertulis untuk mengetahui kemandirian mahasiswa saat mengerjakan konsep diagram gaya dan angket untuk mengetahui tingkat kemandirian mahasiswa serta wawancara untuk menguatkan jawaban yang diperoleh dari hasil tes tertulis dan angket. Hasil penelitian tingkat kemandirian mahasiswa Pendidikan Sains adalah mahasiswa memiliki rasa percaya diri dengan kategori tinggi $69,2 \%$, cukup 30,8\%, indikator inisiatif sendiri dengan kategori tinggi $69,2 \%$ dan cukup 30,8\%, perilaku disiplin mahasiswa pada kategori tinggi $61,5 \%$ dan cukup $38,5 \%$. Akan tetapi, indikator ketidaktergantungan mahasiswa dengan kategori tinggi 30,77\%, cukup 69,23\%, pengontrolan diri mahasiswa dengan kategori tinggi 53,8\%, cukup 46,2\% dan tanggung jawab mahasiswa pada kategori tinggi 30,8\%, cukup 69,2\% yakni kurang memiliki rasa tanggungjawab terhadap penyelasaian tugas karena mereka kurang memiliki keinginan untuk mendapatkan hasil yang memuaskan.
\end{abstract}

Kata Kunci: tingkat kemandirian, diagram gaya

\section{The Independence Level of The Science Education's Student on The Force Diagram Concept}

\begin{abstract}
The objective is to know the level of independence of students of Science Education in the subject of Mechanics on the Force Diagram Concept. This research is descriptive qualitative and its subject is students of $3^{\text {rd }}$ semester in Science Education in the academic year of 2016/2017 academic year. Data collection used the written test to know independence of student when they solved the force diagram concept, questionnaire to know the independence level of student, and interview to confirm their answer of written test and questionnaire. The result of the independence level of Scientific Education's student showed that the students had a high category at $69.2 \%$, a medium at 30,8\%, selfinitiative indicator with a high category at $69.2 \%$, a medium at $30.8 \%$, discipline behavior on a high category at $61.5 \%$, a medium category at $38.5 \%$. However, the indicator of student's dependency with a high category at $30.77 \%$, a medium category at $69.23 \%$, self-control of student on a high category at $53.8 \%$, a medium category at $46,2 \%$ and student responsibility on a high category at $30.8 \%$, a medium category at $69.2 \%$. The students have less responsibility toward solving the task because they have less wish to get a satisfactory result.
\end{abstract}

Keyword: the independence level, the force diagram

DOI : 10.25273/jpfk.v3i2.1348

\section{PENDAHULUAN}

Di dalam kurikulum Pendidikan Sains 2016/2017 bahwa mata kuliah Mekanika merupakan mata kuliah wajib dengan prasyarat mahasiswa telah mengikuti mata kuliah Fisika Dasar I. Hasil dari nilai akhir mahasiswa pada

Copyright (C) 2017, Jurnal Pendidikan Fisika dan Keilmuan(JPFK)

Avaliable online at: http://e-journal.unipma.ac.id/index.php/JPFK

Print ISSN: 2442-8868, Online ISSN: 2442-904X 
mata kuliah Fisika Dasar I menunjukkan 25\% mahasiswa memiliki nikai cukup, $50 \%$ mahasiswa memiliki nilai baik dan $25 \%$ mahasiswa memiliki nilai sangat baik. Mayoritas mahasiswa tersebut memperoleh nilai baik sehingga ini perlu dikaji tentang kemandirian mahasiswa agar mereka dapat menerima dan mampu mengembangkan kemampuan kognitif pada materi kinematika dan dinamika gerak suatu benda. Diagram gaya dipilih sebagai materi penelitian untuk mengukur prestasi dan memberikan konsep gaya dalam kinematika maupun dinamika gerak sehingga mahasiswa semester III diharapkan mampu menguasai materi untuk diajarkan ke peserta didik mereka.

Berdasarkan wawancara dengan dosen Fisika Dasar I ternyata ditemukan beberapa permasalahan selama proses pembelajaran dan ujian mengenai kemandirian yaitu (1) beberapa mahasiswa kurang percaya diri saat menyelesaikan ujian; (2) saat presentasi tugas, beberapa mahasiswa kurang mengembangkan diri dan masih membaca secara detail; (3) secara umum hasil tugas individu mahasiswa sama dengan tugas mahasiswa lainnya; (4) mahasiswa cenderung hanya menggunakan bahan ajar dari dosen; (5) beberapa mahasiswa kurang inisiatif untuk memperoleh wawasan luas melalui sumber informasi lain yang relevan; (6) mahasiswa masih sangat menggantungkan dosen saat penyelesaian tugas. Hal ini mengindikasikan bahwa kemandirian mahasiswa Pendidikan Sains semester III belum terbentuk padahal kemandirian mahasiswa diperlukan tidak hanya mengembangkan pengetahuan saja tetapi juga sikap dan keterampilan mereka.

Data penelitian yang mendukung tentang tingkat kemandirian ini yaitu 53,06\% mahasiswa tingkat kemandiriannya tinggi, $46,50 \%$ sangat tinggi, $0,44 \%$ cukup dan tidak ada yang memiliki tingkat kemandirian rendah (Isorah dan Sumarsih, 2013, p.1). Penelitian pada mata kuliah Mekanika menuliskan bahwa peningkatan (gain) awal dan akhir adalah 0,799, kenaikan tingkat kemandirian ini sekitar 3-4 orang yaitu pada tingkat kemandirian rendah terdapat 2 mahasiswa dibandingkan data awal ada 9 mahasiswa (Yulianti, D., \& Khanafiyah, S., 2012,p.130). Berdasarkan data awal dan penelitian terhadap mahasiswa dari Perguruan Tinggi lain di atas, maka penelitian ini perlu diadakan supaya dapat mengungkap kemandirian mahasiswa Pendidikan Sains STKIP PGRI Nganjuk dan selanjutnya dapat digunakan dosen saat menentukan model pembelajaran yang akan digunakan.

Kemandirian belajar adalah kesediaan untuk belajar yang berasal dari dalam diri mahasiswa sehingga dalam usahanya untuk mencapai tujuan belajar, mahasiswa dapat mengendalikan belajarnya atas pertimbangan, keputusan dan tanggungjawab sendiri, aktif secara individu atau tidak tergantung kepada orang lain (Sumargiyani, 2014, p.843). Kemandirian belajar adalah proses yang mengajak sisiwa melakukan tindakan mandiri yang melibatkan terkadang satu orang biasanya satu kelompok tetapi kemandirian identik dengan belajar madiri tanpa tergantung orang lain (Johnson, E. B., 2008, p.152). Kemandirian mengacu pada persepsi peserta didik bahwa lingkungan pembelajaran bersifat interaktif dan tidak dikendalikan kecuali dirinya (RA Simon et al,2015, p.8).

Kemandirian perlu ditumbuh kembangkan agar terbentuk kepercayaan diri seseorang sehingga tidak sulit untuk menyesuaikan diri, tidak mudah tersinggung, tidak merasa disaingi dan mampu menerima pendapat orang lain (Yulianti, D., 2011, p.98). Mahasiswa perlu memiliki kendali atas materi yang telah diberikan oleh pengajar dengan cara menyelesaikan sendiri agar pemikiran mereka terhadap materi tersebut terakui dan terpadu.

Belajar mandiri menurut Kowles yaitu mahasiswa memiliki inisiatif dengan atau tanpa bantuan orang lain saat menganalisis kebutuhan belajarnya, merumuskan tujuan belajar, mengidentifikasi sumber belajar, memilih dan melaksanakan strategi belajar serta mengevaluasi hasil belajarnya. Beberapa syarat belajar mandiri tersebut diharapkan seseorang mampu mengembangkan kemandirian dan dapat menengelola belajar dengan baik agar hasilnya lebih maksimal (Suardana, I. K., 2012, p.58). Roschester Institute of Technology mengidentifikasi bahwa kemandirian (self regulated learning) memiliki karakterisktik yaitu mahasiswa mengetahui tujuan belajar, menganggap kesulitan sebagai tantangan, mencari dan menggunakan sumber informasi, bekerjasama dengan orang lain, melakukan kontrol diri 
untuk memahami percapaian keberhasilan (Hidayati, K., \& Listyani, E., 2013, p.5).

Penelitian tentang pengembangan instrumen kemandirian memiliki indikator kemandirian sebagai berikut: ketidaktergantungan terhadap orang lain, (2) memiliki kepercayaan diri, (3) berperilaku disiplin, (4) memiliki rasa tanggungjawab, (5) berperilaku berdasarkan inisiatif sendiri dan (6) melakukan kontrol diri (Hidayati, K., \& Listyani, E., 2013, p.9-10). Tingkat kemandirian dapat diukur melalui indikator pengelolaan diri, keinginan untuk belajar, pengendalian diri (Isroah, I., \& Sumarsih, S., 2013, p.3). Hasil penelitian menunjukkan bahwa pengalaman kemandirian belajar siswa dapat dikaitkan dengan bentuk motivasi yang diberikan kepadanya sehingga mampu meningkatkan hasil akdemik. Selain itu, siswa menganggap bahwa dosen mampu mendukung kemandirian melalui kursus pembelajaran (Hall, N., \& Webb, D., 2014, p.19)

Diagram gaya pada mata kuliah Mekanika sebagai materi pembentuk konsep sebelum mengerjakan penyelesaian gaya secara umum menggunakan Hukum Newton. Gaya terbagi menjadi dua yakni gaya langsung dan gaya tak langsung. Gaya langsung merupakan gaya yang bersentuhan/mengenai benda secara langsung. Gaya tak langsung adalah gaya yang bekerja diantara dua benada tetapi kedua benda tersebut tidak bersentuhan, contohnya gaya berat, gaya gravitasi, gaya normal dan gaya sentripetal. Gaya normal adalah gaya yang bekerja pada bidang yang bersentuhan antara dua permukaan benda, yang arahnya tegak lurus dengan bidang sentuh. Jika bidang sentuh arahnya horizontal maka gaya normal memiliki arah vertikal dan sebaliknya. Jika bidang sentuh arahnya miring maka gaya normal memiliki arah miring pula. Gaya berat adalah gaya gravitasi benda terhadap bumi, arah vektornya dimulai dari titik berat benda (pusat benda) menuju ke pusat bumi termasuk ketika bidang sentuh arahnya miring, gaya berat memiliki arah ke bawah (menuju pusat bumi). Gaya yang bekerja pada benda secara langsung (bersentuhan) memiliki arah vektornya berupa tarikan (pangkal vektor) dari permukaan benda atau dorongan (ujung vektor menempel di permukaan benda)
(Giancoli, 2005, p.80). Materi diagram gaya tersebut dapat membuka konsep saat akan menyelesaikan gaya-gaya yang bekerja pada persamaan-persamaan Hukum I, II, dan III Newton. Berdasarkan hal-hal di atas, penelitian ini bertujuan untuk mengetahui tingkat kemandirian mahasiswa Pendidikan Sains pada mata kuliah Mekanika dengan konsep Diagram Gaya.

\section{METODE}

\section{Jenis Penelitian}

Penelitian ini menggunakan pendekatan kualitatif.

\section{Waktu dan Tempat Penelitian}

Penelitian dilaksanakan pada bulan September sampai Desember Tahun Akademik 2016/2017 di STKIP PGRI Nganjuk.

\section{Subjek Penelitian}

Subjek penelitian ini adalah seluruh mahasiswa Pendidikan Sains semester III yang menempuh mata kuliah Mekanika pada tahun 2016/2017. Subjek ini dipilih menggunakan metode purposive sampling.

\section{Prosedur}

Penelitian ini termasuk eksperimental dengan rancangan quasi ekperimental.

\section{Teknik Pengumpulan Data}

Data dikumpulkan melalui tes tertulis, angket dan wawancara. Indikator tingkat kemandiran mahasiswa meliputi ketergantungan terhadap orang lain, memliki kepercayaan diri, berperilaku disiplin, memiliki rasa tanggungjawab, berperilaku berdasarkan inisiatif sendiri dan melakukan kontrol diri. Angket menggunakan skala Likert (1-4) terdiri 24 soal valid dan 1 soal tidak valid sehingga yang digunakan 24 soal.

\section{Teknik Analisis Data}

Teknik analisis data yang digunakan adalah deskriptif kualitatif dengan prosentase. Kemandirian mahasiswa dianalisis dengan kriteria ideal sesuai kategori sebagai berikut: 
Jurnal Pendidikan Fisika dan Keilmuan (JPFK) Vol 3 No 2 September 2017, hal 78-87

Avaliable online at: http://e-journal.unipma.ac.id/index.php/JPFK

Print ISSN: 2442-8868, Online ISSN: 2442-904x

Tabel 1. Kategori Kemandirian Mahasiswa

\begin{tabular}{ccc}
\hline No. & Kategori & Rentang \\
\hline 1. & Tinggi & $>\mathrm{Mi}+(1,5 \times \mathrm{SDi})$ \\
2. & Sedang & $\mathrm{Mi}-(1,5 \times \mathrm{SDi})$ sampai dengan Mi + (1,5 x SDi $)$ \\
4. & Rendah & $<\mathrm{Mi}-(1,5 \times \mathrm{SDi})$ \\
\hline
\end{tabular}

dengan perhitungan prosentase nilai sebagai berikut:

(Isroah, I., \& Sumarsih, S., 2013)

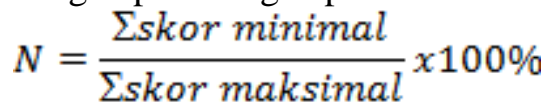

\section{HASIL DAN PEMBAHASAN}

Prosentase tingkat kemandirian berdasarkan indikatornya terdapat dalam tabel 2. Berdasarkan hasil penelitian angket dan wawancara serta tugas-tugas yang telah dilakukan terhadap mahasiswa Pendidikan

Sains untuk mengetahui tingkat kemandirian mahasiswa sebagai berikut ini:

Tabel 2. Prosentase Tingkat Kemandirian Mahasiswa Pendidikan Sains

\begin{tabular}{lcc}
\hline \multirow{2}{*}{\multicolumn{1}{c}{ Indikator }} & \multicolumn{2}{c}{ Kategori } \\
\cline { 2 - 3 } & Tinggi & Cukup \\
\hline Ketidaktergantungan terhadap orang lain & 30,77 & 69,23 \\
Memiliki kepercayaan diri & 69,20 & 30,80 \\
Berperilaku disiplin & 61,50 & 38,50 \\
Memiliki rasa tanggungjawab & 30,80 & 69,20 \\
Berperilaku berdasarkan inisiatif sendiri & 69,20 & 30,80 \\
Melakukan kontrol diri & 53,80 & 46,20 \\
\hline
\end{tabular}

Tabel 3. Hasil Tes Kognitif Mahasiswa A dan B pada Konsep Penguraian Diagram Gaya

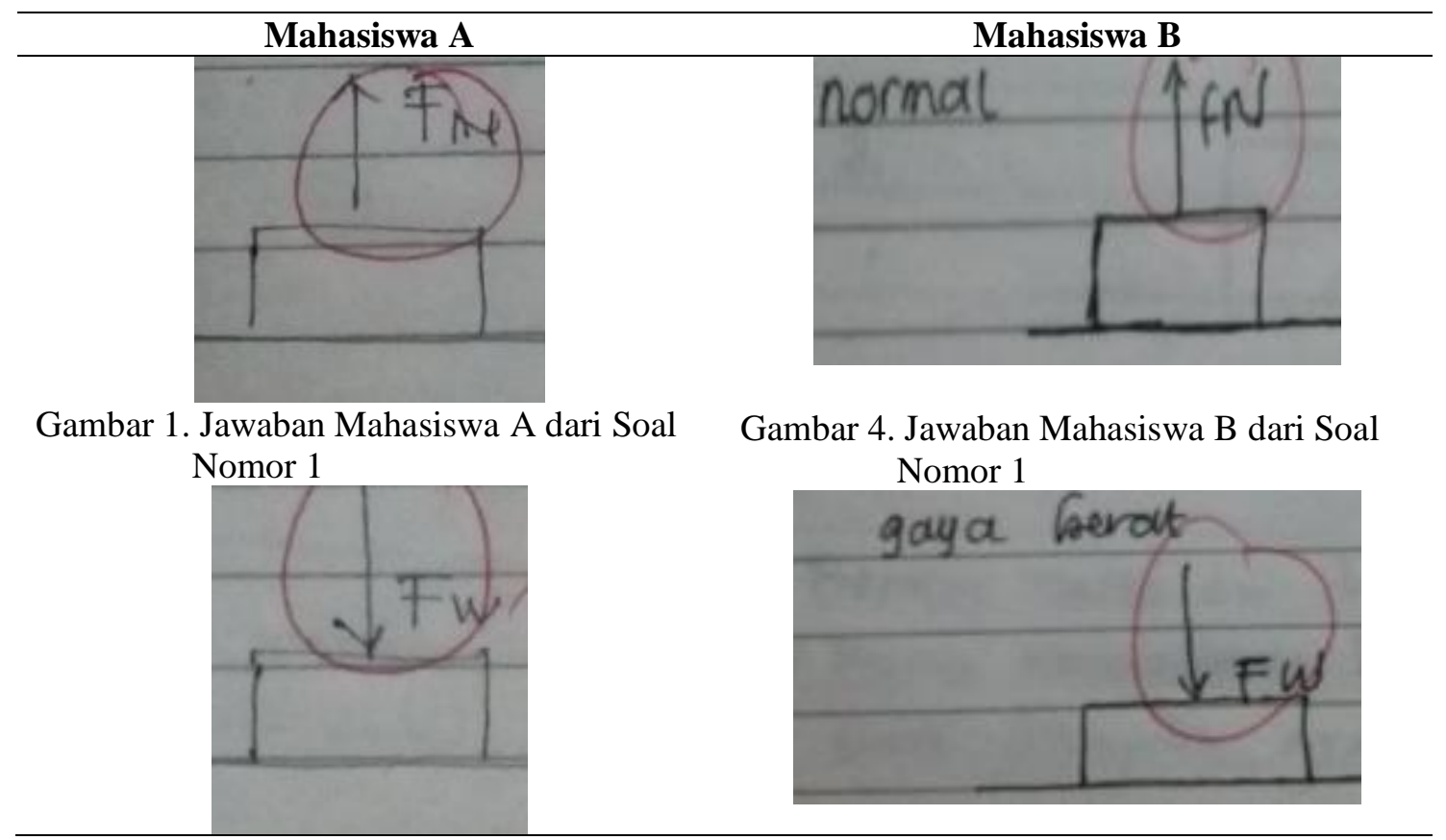




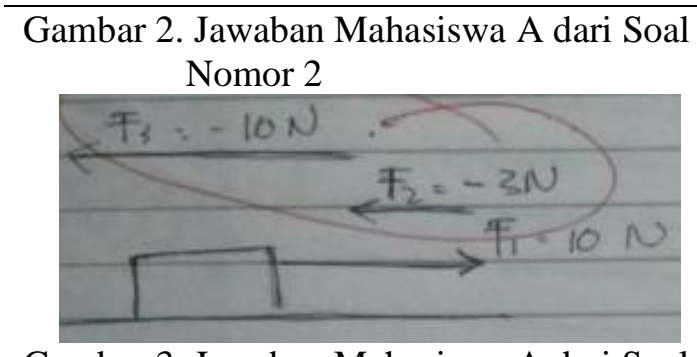

\author{
Gambar 5. Jawaban Mahasiswa B dari Soal \\ Nomor 2
}

Gambar 3. Jawaban Mahasiswa A dari Soal Nomor 3

Mahasiswa B tidak mengerjakan soal nomor 3,4 , dan 5 .

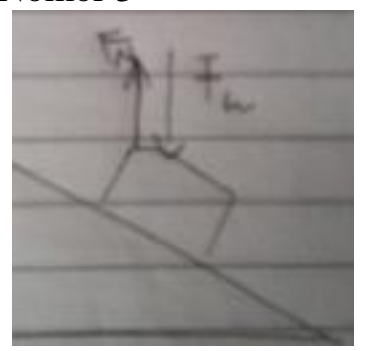

Gambar 4. Jawaban Mahasiswa A dari Soal Nomor 4

Mahasiswa A tidak mengerjakan soal nomor 5.

Berdasarkan jawaban mahasiswa $\mathrm{A}$ diketahui bahwa semua jawabannya kurang tepat karena tidak sesuai konsep diagram gaya. Hal ini sesuai dengan hasil wawancaranya bahwa gaya normal dianggap arahnya ke atas sedangkan gaya berat arahnya ke bawah seperti jawaban di nomor 1 dan 4. Pada soal nomor 3 diperoleh bahwa arah ketiga gaya sudah benar tetapi gambar vektor gaya seharusnya menempel benda dan perbandingan panjang vektor gaya $-3 \mathrm{~N}$ dengan $10 \mathrm{~N}$ dan $10 \mathrm{~N}$ kurang tepat. Hasil angket serta wawancara dihasilkan bahwa mahasiswa tersebut tergolong orang yang memiliki kepercayaan diri, tidak tergantung terhadap orang lain, disiplin tetapi kurang bertanggungjawab karena mahasiswa tersebut tidak menyelesaikan semua tugas. Berdasarkan data di atas, mahasiswa kurang mampu mengontrol diri karena merasa sering kurang teliti setiap mengerjakan tugas atau ujian.

Tabel 4. Hasil Tes Kognitif Mahasiswa C dan D pada Konsep Penguraian Diagram Gaya

Hasil wawancara dari mahasiswa B menunjukkan bahwa jawaban soal nomor 1 dan 2 adalah hasil menggantungkan jawaban dari orang lain. Sesuai dari hasil angket yang telah disebarkan menunjukkan bahwa mahasiswa B kurang memiliki kepercayaan diri serta kurang berinisiatif melakukan belajar atas kemauannya sendiri. Dari indikator disiplin, mahasiswa B ini tergolong mahasiswa yang disiplin karena kehadirannya dan mengumpulkan tugas dengan tepat waktu. Akan tetapi mahasiswa B kurang memiliki rasa tanggung jawab sebab tugas-tugas yang dikumpulkan tidak semuanya dikerjakan sehingga mahasiswa ini termasuk mudah menyerah serta kurang memiliki kontrol diri. Dari data hasil angket dan wawancara terungkap bahwa mahasiswa B tidak pernah melakukan evaluasi hasil belajarnya. 
Jurnal Pendidikan Fisika dan Keilmuan (JPFK) Vol 3 No 2 September 2017, hal 78-87

Avaliable online at: http://e-journal.unipma.ac.id/index.php/JPFK

Print ISSN: 2442-8868, Online ISSN: 2442-904x

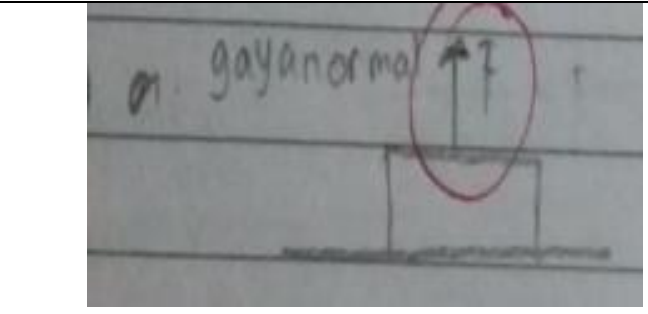

Gambar 6. Jawaban Mahasiswa C dari Soal Nomor 1

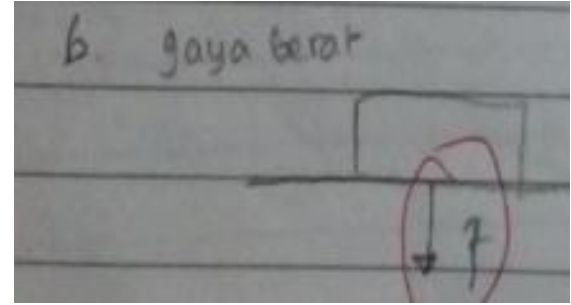

Gambar 7. Jawaban Mahasiswa C dari Soal Nomor 2

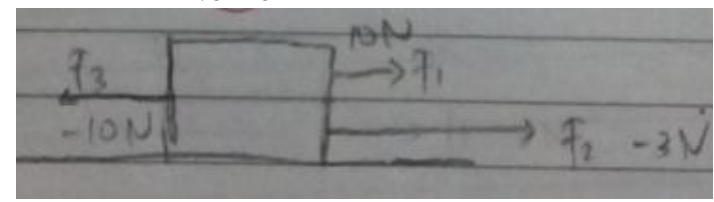

Gambar 8. Jawaban Mahasiswa C dari Soal Nomor 3

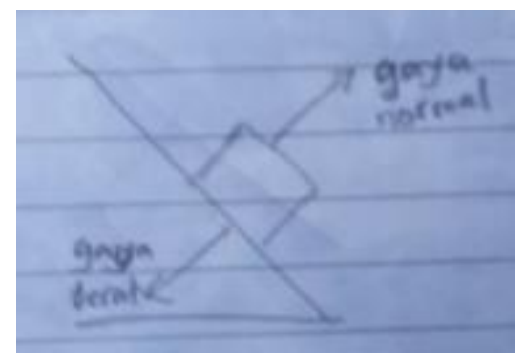

Gambar 9. Jawaban Mahasiswa C dari Soal Nomor 4

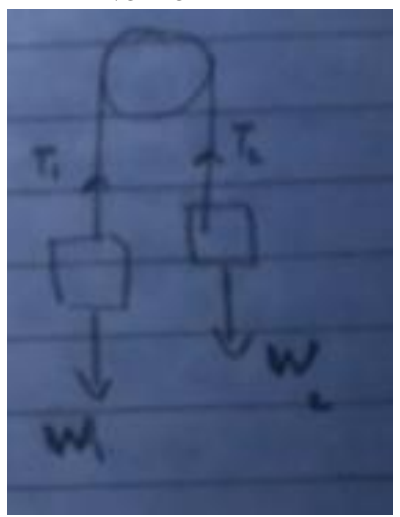

Gambar 10. Jawaban Mahasiswa C dari Soal Nomor 5

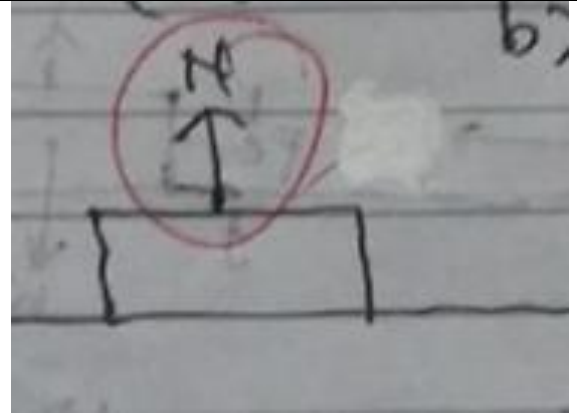

Gambar 11. Jawaban Mahasiswa D dari Soal Nomor 1

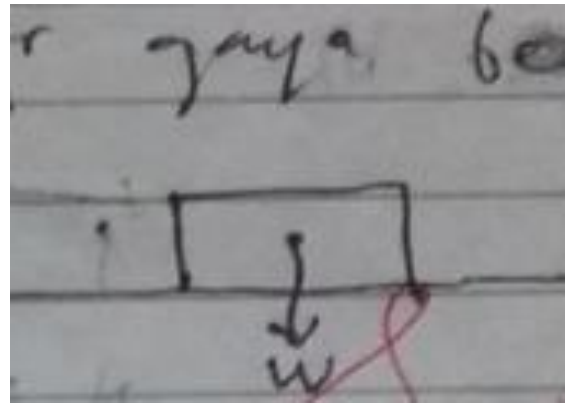

Gambar 12. Jawaban Mahasiswa D dari Soal Nomor 2

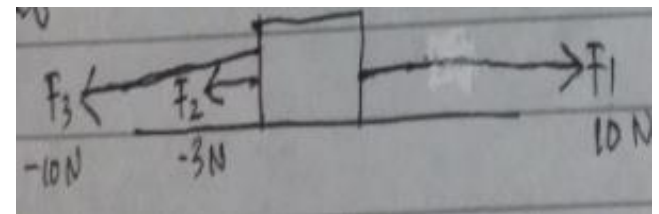

Gambar 13. Jawaban Mahasiswa D dari Soal Nomor 3

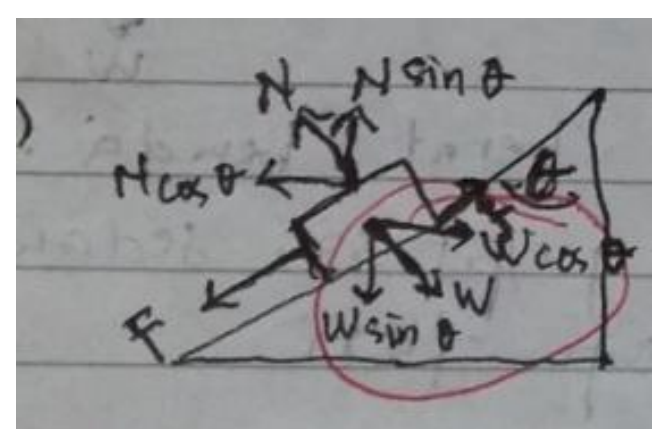

Gambar 14. Jawaban Mahasiswa D dari Soal Nomor 4 


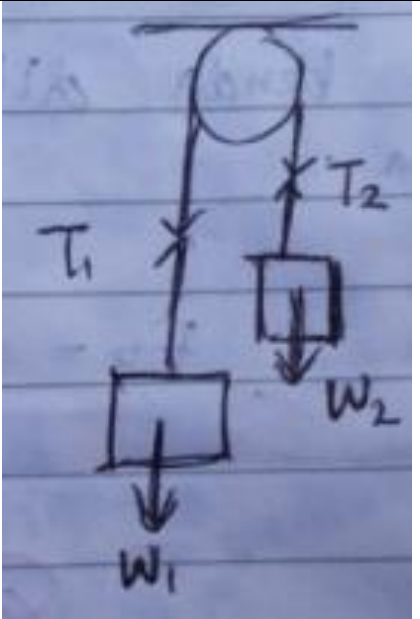

Gambar 15. Jawaban Mahasiswa D dari Soal

Nomor 5

Hasil tugas dan wawancara dari mahasiswa $\mathrm{C}$ menghasilkan penyelesaian soal pada nomor 1 dan 2 memiliki jawaban yang tidak tepat karena tidak sesuai konsep diagram gaya normal dan berat. Pada nomor 3 memiliki jawaban yang tidak tepat pula sebab uraian gaya $-3 \mathrm{~N}$ seharusnya mengarah ke kiri dan panjang vektor $-3 \mathrm{~N}, 10 \mathrm{~N}$ dan $-10 \mathrm{~N}$ tidak sesuai perbandingannya misal $10 \mathrm{~N}$ dan $-10 \mathrm{~N}$ seharusnya memiliki panjang yang sama dan 3N memiliki panjang yang lebih pendek. Pada soal nomor 4 , mahasiswa $\mathrm{C}$ beranggapan sama dengan jawaban nomor 1 dan 2 yakni gaya normal tegak lurus dengan permukaan bidang miring tetapi jawabannya kurang tepat sebab panjang vektornya tidak bersentuhan dengan bidang miring, jawaban diagram gaya berat juga tidak tepat sebab gaya berat dianggap tegak lurus dengan permukaan benda. Pada soal nomor 5, mahasiswa $\mathrm{C}$ menggambarkan gaya berat dimana panjang vektornya tidak dimulai dari titik berat benda tetapi dari permukaan benda yang mengarah ke bawah. Berdasarkan data angket kemandirian dan wawancara atas jawaban di atas, diketahui bahwa mahasiswa $\mathrm{C}$ tidak memiliki ketergantungan terhadap orang lain dan memiliki rasa percaya yang tinggi dan memiliki inisiatif belajar dan menjawab sendiri karena kelima jawabannya tidak ada yang sama dengan mahasiswa lain. Selain itu mahasiswa ini juga memiliki disiplin yang tinggi dari ketepatan hadir dan mengumpulkan tugas serta bertanggungjawab atas tugas yang harus diselesaikan tanpa menggantungkan dosen meskipun kelima jawabannya kurang tepat. Dari data di atas, wawancara dengan mahasiswa $\mathrm{C}$ diketahui kurang dapat mengontrol diri sebab sering melihat tugas teman terlebih dahulu dibanding mencari sumber referensi sendiri dan kurang teliti.

Wawancara dari hasil tugas mahasiswa D menghasilkan bahwa nomor 1 memiliki jawaban yang kurang tepat sebab mahasiswa tersebut beranggapan bahwa gambar diagram gaya normal dimulai dari permukaan atas benda tetapi arah gaya normal sudah benar yakni tegak lurus dengan permukaan bidang gerak, terlihat pula jawaban nomor 1 terulang di jawaban nomor 4. Diagram gaya berat pada nomor 2, 4 dan 5 dimulai dari titik yang benar yaitu pusat benda, tetapi pada nomor 4 memiliki arah yang kurang tepat sebab mahasiswa beranggapan bahwa digram gaya berat tegak lurus dengan permukaan benda. Pada soal nomor 5 memiliki jawaban yang benar pada gambar diagram tegangan tali dengan arah vektor yang saling berlawanan. Dapat disimpulkan bahwa mahasiswa D termasuk tidak menggantungkan orang lain, memiliki kepercayaan diri, berinisiatif sendiri, disiplin, bertanggungjawab dan mampu mengontrol diri. Hal ini terbukti dari hasil angket, wawancara bahwa mahasiswa tersebut lebih percaya jawaban dan tugas dari hasil sendiri serta berusaha mencari sumber informasi tanpa menunggu perintah dari dosen, tepat waktu selama pengerjaan tugas dan berusaha mengisi semua soal meskipun ada beberapa konsep diagaram gaya yang perlu dibenarkan. 

Jurnal Pendidikan Fisika dan Keilmuan (JPFK) Vol 3 No 2 September 2017, hal 78-87

Avaliable online at: http://e-journal.unipma.ac.id/index.php/JPFK

Print ISSN: 2442-8868, Online ISSN: 2442-904x

Tabel 5. Hasil Tes Kognitif Mahasiswa E dan F pada Konsep Penguraian Diagram Gaya

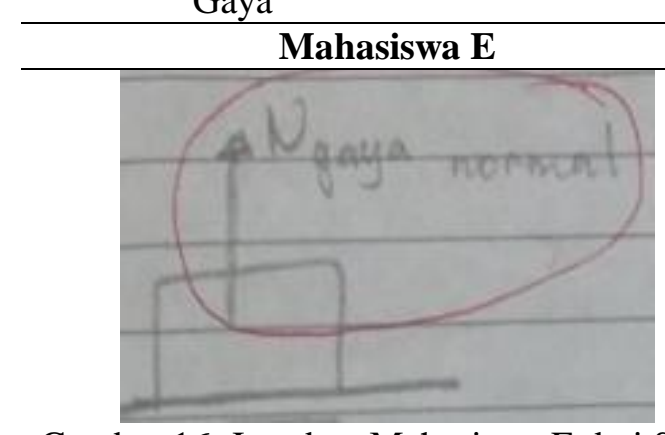

Gambar 16. Jawaban Mahasiswa E dari Soal Nomor 1

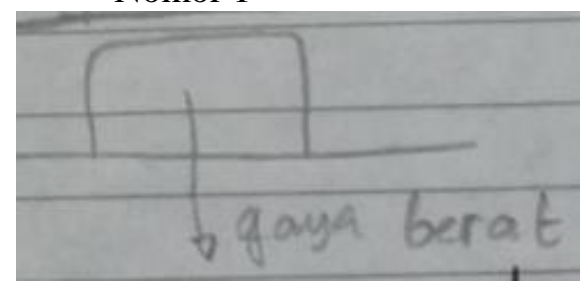

Gambar 17. Jawaban Mahasiswa E dari Soal Nomor 2

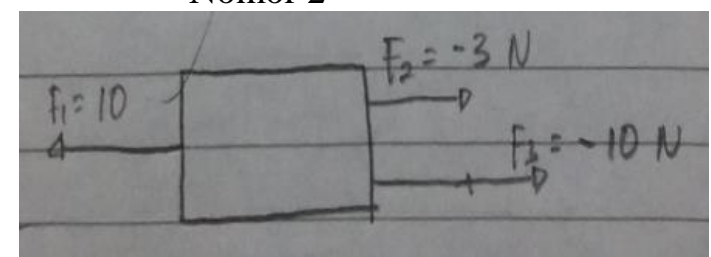

Gambar 18. Jawaban Mahasiswa E dari Soal Nomor 3

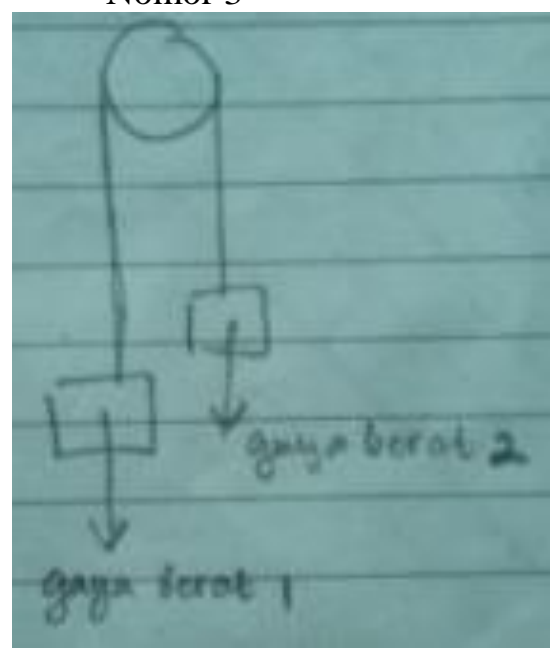

Gambar 19. Jawaban Mahasiswa E dari Soal Nomor 5

Mahasiswa E tidak mengerjakan soal nomor 4.

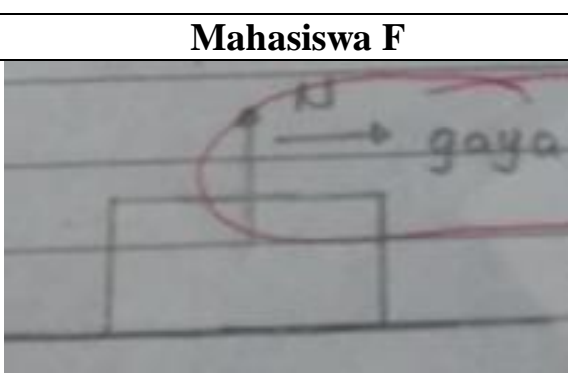

Gambar 20. Jawaban Mahasiswa F dari Soal Nomor 1

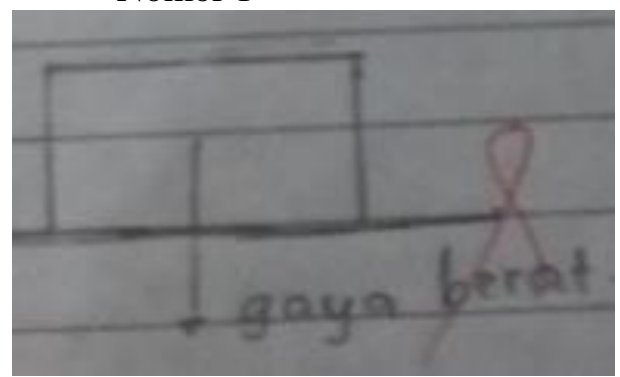

Gambar 21. Jawaban Mahasiswa F dari Soal Nomor 2

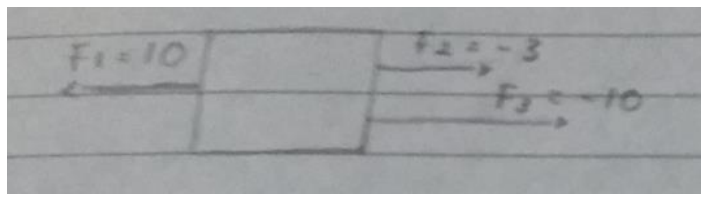

Gambar 22. Jawaban Mahasiswa F dari Soal Nomor 3

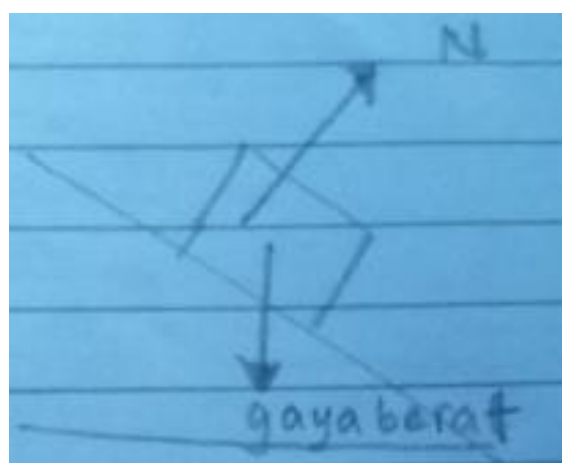

Gambar 23. Jawaban Mahasiswa F dari Soal Nomor 4 


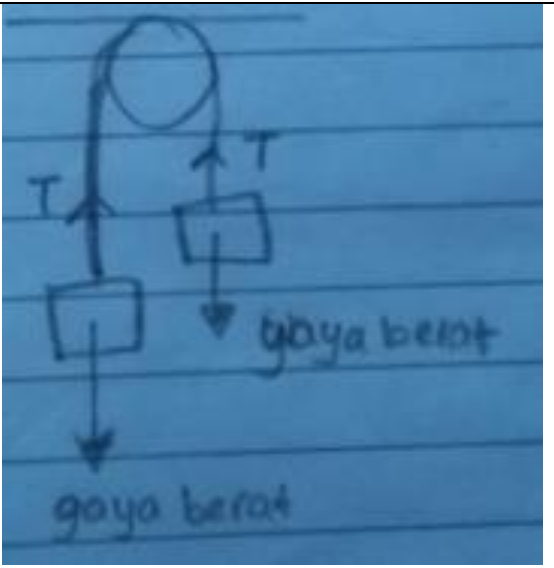

Gambar 24. Jawaban Mahasiswa F dari Soal

Nomor 5

Berdasarkan hasil angket dan
wawancara terhadap mahasiswa $\mathrm{E}$, diperoleh bahwa jawabannya adalah hasil dari menggantungkan orang lain sebab mahasiswa tersebut kurang yakin jawabannya sendiri sehingga termasuk kurang mampu mengontrol diri. Selain itu, mahasiswa kurang memiliki inisiatif sendiri dan kurang bertanggungjawab. Pada soal nomor 4, mahasiswa tersebut tidak berusaha mengerjakan dari pengetahuan awal maupun mencari sumber informasi selama pembelajaran dan cenderung menunggu pembahasan soal bersama teman maupun dosen. Dari segi disiplin, mahasiswa tersebut berusaha tepat waktu untuk mengumpulkan tugas namun tidak memperhatikan hasil akhirnya beserta dampaknya.

Hasil tugas dan wawancara kepada mahasiswa $\mathrm{F}$ diperoleh pada soal nomor 1 dan 4 memiliki jawaban yang kurang tepat karena beranggapan bahwa gambar vektor gaya normal dari dalam benda meskipun arahnya benar yakni tegak lurus dengan permukaan bidang gerak. Gaya berat pada nomor 2, 4 dan 5 memiliki jawaban yang benar sebab mahasiswa tersebut beranggapan bahwa gaya berat mengarah ke pusat bumi dan gambar vektornya dimulai dari titik berat benda. Gambar vektor gaya tegang tali pada nomor 5 kurang tepat sebab di gambar tersebut tidak menunjukkan tegangan pada tali tetapi seperti ada tarikan disetiap benda yang arahnya ke atas. Pada nomor 3 memiliki jawaban yang salah sebab arah vektor $-3 \mathrm{~N}$ seharusnya ke kiri meskipun panjang vektor $-3 \mathrm{~N}$ lebih pendek dibanding $10 \mathrm{~N}$ dan $-10 \mathrm{~N}$ serta perbandingan panjang vektornya kurang tepat. Hasil angket kemandirian dan wawancara bahwa nomor 1, 2 dan 3 sama persis dengan mahasiswa E. Hal ini mengindikasikan antara mahasiswa $\mathrm{E}$ dan $\mathrm{F}$ memiliki sikap menggantungkan kepada orang lain tetapi mahasiswa $\mathrm{F}$ lebih mampu mengontrol diri karena dia dapat mengatasi kesulitan saat mengerjakan tugas dengan kemampuannya sendiri terlihat bahwa kelima soal dikerjakan walaupun hasilnya kurang memuaskan. Selain itu, mahasiswa F tergolong bertanggungjawab, memiliki insiatif sendiri dan memiliki kepercayaan diri.

Hasil penelitian menghasilkan bahwa kemandirian mahasiswa Pendidikan Sains sesuai tabel 2 memiliki ketidaktergantungan terhadap orang lain dengan kategori tinggi $30,77 \%$, cukup $69,23 \%$. Data ini didukung dengan indikator mengontrol diri mahasiswa dengan kategori tinggi 53,8\% yang mengindikasikan beberapa mahasiswa yang kurang mampu mengontrol diri yaitu melihat tugas teman terlebih dahulu dibanding mencari sumber referensi walaupun mereka masih mampu meneliti tugas-tugasnya dan tidak menanti pembahasan dari dosen sedangkan mahasiswa dengan kategori cukup 46,2\% menunjukkan bahwa mahasiswa tersebut lebih dahulu melihat tugas teman, tidak teliti sekaligus menanti pembahasan dari dosen. Kepercayaan diri mahasiswa satu dengan yang lainnya tergolong tinggi $69,2 \%$ dan cukup $30,8 \%$ meskipun dengan hasil jawaban yang kurang memuaskan. Data tersebut sesuai dengan perilaku mahasiswa saat pembelajaran maupun mengerjakan tugas sesuai inisiatifnya sendiri dengan kategori tinggi 69,2\% dan cukup 30,8\%. Mahasiswa yang memiliki perilaku disiplin tinggi $61,5 \%$ dan cukup $38,5 \%$ sedangkan tanggung jawab kategori 
tinggi 30,8\% dan cukup 69,2\% kedua indikator ini bertolak belakang sebab terdapat beberapa mahasiswa yang memiliki perilaku disiplin yaitu tepat waktu kehadiran dan pengumpulan tugas namun kurang bertanggungjawab atas penyelesaian soal secara keseluruhan. Hasil penelitian dari kelima indikator kemandirian tersebut menunjukkan ketidakseimbangan sehingga perlu adanya peningkatan tanggung jawab dengan cara melatih mahasiswa untuk mengerjakan terlebih dahulu sampai selesai setelah itu dosen memberikan bimbingan, mahasiswa dituntut untuk mencari sumber informasi dari berbagai media agar mendapatkan referensi untuk penyelesaian tugas dan membina mahasiswa dengan adanya study club supaya mereka dapat berdiskusi secara intensif dengan teman sebaya maupun dosen.

\section{KESIMPULAN}

Berdasarkan data penelitian dan pembahasan di atas dapat disimpulkan bahwa mereka menunjukkan rasa percaya diri, berinisiatif sendiri dan disiplin atas ketepatan waktu mengerjakan. Akan tetapi, mahasiswa kurang mampu mengontrol diri dan saling menggantungkan satu sama lain serta kurang memiliki rasa tanggungjawab terhadap penyelasaian tugas karena mereka kurang memiliki keinginan untuk mendapatkan hasil yang memuaskan. Oleh sebab itu, perlu adanya tindakan selanjutnya untuk meningkatkan keseimbangan dari kelima indikator tersebut agar tercapai kemandirian yang diharapkan dengan cara melatih mahasiswa untuk mengerjakan terlebih dahulu sampai selesai, mahasiswa dituntut untuk mencari sumber informasi, dan membina mahasiswa dengan adanya study club.

\section{DAFTAR PUSTAKA}

Giancoli, Douglas C. (2005). Physics: Principles with Application Sixth Edition. New Jersey: Pearson Prentice Hall.

Hall, N., \& Webb, D. (2014). Instructors' Support Of Student Autonomy In An Introductory Physics Course. Physical Review Special Topics-Physics Education Research, 10(2), 1-22.

Hidayati, K., \& Listyani, E. (2013). Improving Instruments Of Students'self-
Regulated Learning.

http://staffnew.uny.ac.id/upload/13229

6141/penelitian/Pengembangan+Instru men.pdf )

Isroah, I., \& Sumarsih, S. (2013). Analisis Kemandirian Belajar Mahasiswa Program Studi Pendidikan Akuntansi Fakultas Ilmu Sosial Dan Ekonomi Universitas Negeri Yogyakarta. Jurnal Pendidikan Akuntansi Indonesia, 11(1), 1-12.

Johnson, E. B. (2008). Contextual Teaching and Learning. terj. Ibnu Setiawan, Bandung: $M L C$.

RA Simon, MW Aulls, H Dedic, K Hubbard dan NC Hall. (2015). Exploring Student Persistence in STEM Programs: A Motivational Model. Canadian Journal of Education, 38 (1), 1-27.

Suardana, I. K. (2012). Implementasi Model Belajar Mandiri Untuk Meningkatkan Aktivitas, Hasil, Dan Kemandirian Belajar Mahasiswa. Jurnal Pendidikan Dan Pengajaran, 45(1), 56-65.

Sumargiyani. (2014). Peningkatan Kemandirian Belajar kalkulus Lanjut menggunakan Metode Pengembangan Pembelajaran Kooperatif Snowball Drilling. Prosiding Seminar Nasional Sains dan Pendidikan Sains IX yang diselenggarakan oleh Fakultas Sains dan Matematika, tanggal 21 Juni 2014, 5 (1). Salatiga: UKSW

Yulianti, D. (2011). Pengembangan Bahan Ajar Mekanika I Berbasis E-Learning Untuk Mengembangkan Kemandirian Mahasiswa. Jurnal Penelitian Pendidikan, 28(2), 96-105.

Yulianti, D., \& Khanafiyah, S. (2012). Penerapan Virtual Experiment Berbasis Inkuiri Untuk Mengembangkan Kemandirian Mahasiswa. Jurnal Pendidikan Fisika Indonesia, 8(2), 127-134. 